\title{
Macroflocs: Production of Marine Snow in the Laboratory
}

\author{
Kate Kranck and T. Milligan
}

Atlantic Oceanographic Laboratory, Bedford Institute of Oceanography, Dartmouth, Nova Scotia, B2Y 4A2, Canada

\begin{abstract}
Large suspended aggregates similar to 'marine snow' have been obtained by placing natural and artificially produced particulate matter in a vertical recirculating tube with an upward flowing turbulent current. At flow rates as high as $0.25 \mathrm{~cm} \mathrm{~s}^{-1}$ the seawater suspension settled out as macroflocs which incorporated all the components in suspension. The size and shape of the particles produced by physiochemical flocculation varied with flow rate and floc composition.
\end{abstract}

\section{INTRODUCTION}

Large suspended aggregates are known to occur in the sea. Early sightings from submersibles describe irregular flocculated material, up to several centimeters in size, named 'marine snow' (Suzuki and Kato, 1953; Nishizawa et al., 1954; Inoue et al., 1955). Recent studies (Jannasch, 1973; Alldredge, 1976; Silver et al., 1978; Trent et al., 1978; Alldredge, 1979; Shanks and Trent, 1979) using mainly SCUBA for sample collection, along with modern analytical techniques, have confirmed that a large proportion of the suspended matter in the open ocean is structured into large aggregates. A variety of shapes and sizes are found, including irregular loose masses, long stringers of veil-like material and more compact rounded structures. Concentrations also vary, both seasonally and regionally; counts of up to 27 particles greater than $0.5 \mathrm{~mm} \mathrm{l}^{-1}$ have been observed. The structure of this marine snow is delicate, and flocs shatter on sampling and handling. Floc composition can be assessed only by comparison with the particulate matter in the surrounding water.

The aggregates have settling rates of the order of tens to hundreds of $\mathrm{m} \mathrm{d}^{-1}$, considerably higher than settling rates estimated for discrete suspended grains (Alldredge, 1979). The resulting downward flux is in accord with the relatively rapid transfer of particulate matter from the surface to the depths, as indicated by the gradients of chemicals in the water column and sedimentation in midwater sedimentation traps (Edmond, 1974; Krisnaswami and Saris, 1976; Wiebe et al., 1976; Bewers and Yeats, 1977; Bishop et al., 1977;
Honjo, 1977; Hargrave and Taguchi, 1978; Spencer et al., 1978; Rowe and Gardner, 1979; Prahl and Carpenter, 1979). Fecal pellets produced by planktonic organisms have been suggested to act as packaging mechanism for accelerated settling, but only a fraction of the material arriving at lower depths can be identified as fecal pellets (Wiebe et al., 1976; Bishop et al., 1977; Honjo, 1977; Hargrave and Taguchi, 1978; Prahl and Carpenter, 1979). Bishop et al. (1977), calculated particle fluxes of in situ filtered matter in which the original in situ particle diameter could be distin-

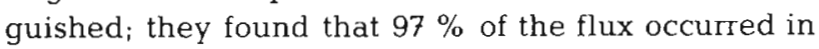
the form of large irregularly shaped low-density aggregate particles. These particles were similar to macroaggregates described from surface waters, but quite different from fecal pellets, also present but rare in comparison.

This organization of particulate matter differs considerably from that indicated by analysis of water samples, according to which the occurrence of particles greater than $100 \mu \mathrm{m}$ is rare (Riley, 1963; Gordon, 1970). Although the occurrence of large flocs and aggregates has been known in the past (Riley, 1963; Riley et al., 1963), it is now apparent that they are the dominant factor in the behaviour and transfer of particulate matter in the open sea.

While there have been no systematic in situ observations of grain size in the more turbid shallow waters of estuaries and nearshore regions, descriptions by submariners and divers indicate that particles are commonly large enough to be seen with the naked eye, and that they consist of aggregates. Indirect evidence for 
the existence of large aggregates comes from rapid changes in particle concentrations observed in very turbid coastal waters, especially estuaries. Krone (1972) calculated settling rates of up to $4.5 \mathrm{~cm} \mathrm{~s}^{-1}$ for suspended sediment in the Savannah estuary (Georgia, USA), but grain-size determinations performed on water samples seldom show the presence of particulate matter larger than $100 \mu \mathrm{m}$ in inshore water (Schubel, 1969; Kranck, 1975, 1979). Again, fecal pellets have been suggested as a means of resolving the difference between apparent settling rates and measured grain sizes (Drake, 1976). A more likely explanation is the formation of rapidly settling large flocs similar to open-ocean 'marine snow', although the inclusion of more inorganic matter in the nearshore material, resulting in higher floc density, probably causes them to settle out before the extreme sizes found in the open ocean are reached.

The significance of macroflocs in terms of microenvironments for plankton production, nutrient regeneration, transfer of organic matter to the benthic community, and other ecological processes, has been recognized and discussed (Riley, 1963, 1970; Riley et al., 1963; Alldredge, 1979; Shanks and Trent, 1979). Relatively little, however, has been said about the origin and formation of marine snow. Flocculation, whereby large particles capture smaller particles, has been suggested as a mechanism (Riley et al., 1963; Riley, 1963. 1970; Alldredge, 1979) but some active biological mechanism was usually also suggested or implied. For example Bishop et al. (1977) refer to their large flocculent aggregates as 'fecal matter', thereby discounting an entirely physical origin of the aggregate structure.

In this paper we describe the artificial production of large suspended particles which we believe are similar in appearance and origin to marine snow particles. We also discuss some relevant observations.

\section{MATERIAL AND METHODS}

To produce an artificial environment where particies could be kept in suspension under controlled flow conditions, seawater was circulated in a $100 \mathrm{~cm}$ long, $80-\mathrm{cm}$ diameter, vertical glass tube tapered at the lower end (Fig. 1a). An upward vertical flow $(0.01 \mathrm{~cm}$ $\mathrm{s}^{-1}$ to $0.25 \mathrm{~cm} \mathrm{~s}^{-1}$ ) was maintained by an oscillating pump. The flow within the tube was turbulent, with a Reynolds number of ca. 10 to 200. At the start of an experiment, artificial suspensions of particulate matter were injected into the tube through a stopcock at the bottom. The pump was run at maximum speed for a few minutes to produce an even suspension and then adjusted to produce the desired upwelling rate. A
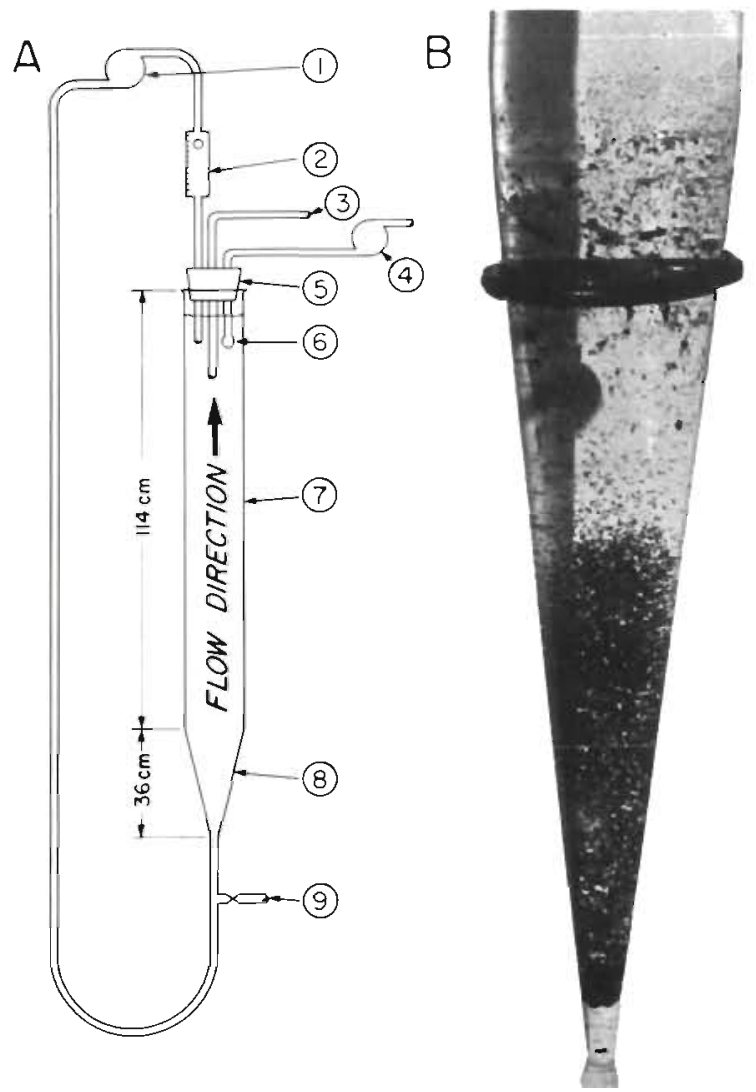

Fig. 1. (A) Recirculating apparatus. Upward-current speed in tube (7) represents the minimum settling rate which particles must obtain through flocculation before settling out in the cone. 1: Oscillating pump; 2 : flow meter; 3 : sampling tube; 4 . air pump; 5: rubber stopper; 6 : bubbling stone; 7 : glass tube; 8: glass cone; 9: stoppered hose. (B) Photograph of cone after most of the particulate matter introduced into the recirculating system has concentrated in the cone as large macroflocs

bubbling stone at the top of the tube aerated the suspension.

Organic particulate matter was obtained - by the use of an Osterizer blender - from seaweed, fish, and suspended material of a size greater than $100 \mu \mathrm{m}$, screened from water pumped from the Bedford Basin. The suspended material consisted of zooplankton and organic detritus. Sediment was obtained from a deposit of glacial marine clay from Sillikers, New Brunswick. It consisted of clay minerals, traces of quartz and feldspar, and $3 \%$ (by weight) organic matter, had a modal size of $12 \mu \mathrm{m}$, and contained very little material larger than $30 \mu \mathrm{m}$. These test materials were prepared as thick slurries, poured through a $125 \mu \mathrm{m}$ nytex screen, and disaggregated with an ultrasonic probe just prior to injection into the tube. Initial concentrations of particulate matter in the tube ranged from 5 to $250 \mathrm{ppm}$. As the experiments progressed samples were withdrawn from the top of the tube at intervals and run through a Coulter Counter to determine concentrations 
and grain sizes remaining in suspension. Optical analyses were also made using a Zeiss inverted microscope.

\section{RESULTS}

In the over 20 experiments carried out the following sequence of events occurred. Usually within $1 \mathrm{~h}$ of slurry injection, and always within $24 \mathrm{~h}$, large particles became visible in the suspension. Their size and number increased with time. Eventually the largest particles started to settle against the upward flow of water and collect in the bottom cone. In the tube the particle size appeared varied, ranging from easily visible very large flocs of $10 \mathrm{~mm}$ maximum dimension to the fine material of the turbid background (Fig. 2). The largest flocs accumulated in the cone. The water in the tube became progressively clearer at rates depending on the type of material used. Total time until the fluid cleared ranged from less than $24 \mathrm{~h}$ to several days

Shapes and sizes of visible particles were different for different flow rates and particle compositions. The inorganic sediment formed spheres of up to about $1 \mathrm{Inm}$ in diameter at relatively high flow rates $0.1 \mathrm{~cm}$ $\left.\mathrm{s}^{-1}\right)$. At lower rates $\left(0.01 \mathrm{~cm} \mathrm{~s}^{-1}\right)$, long strings or chains of mineral grains formed, parallel to the direction of flow. Organic matter and mixtures of organic and inor-
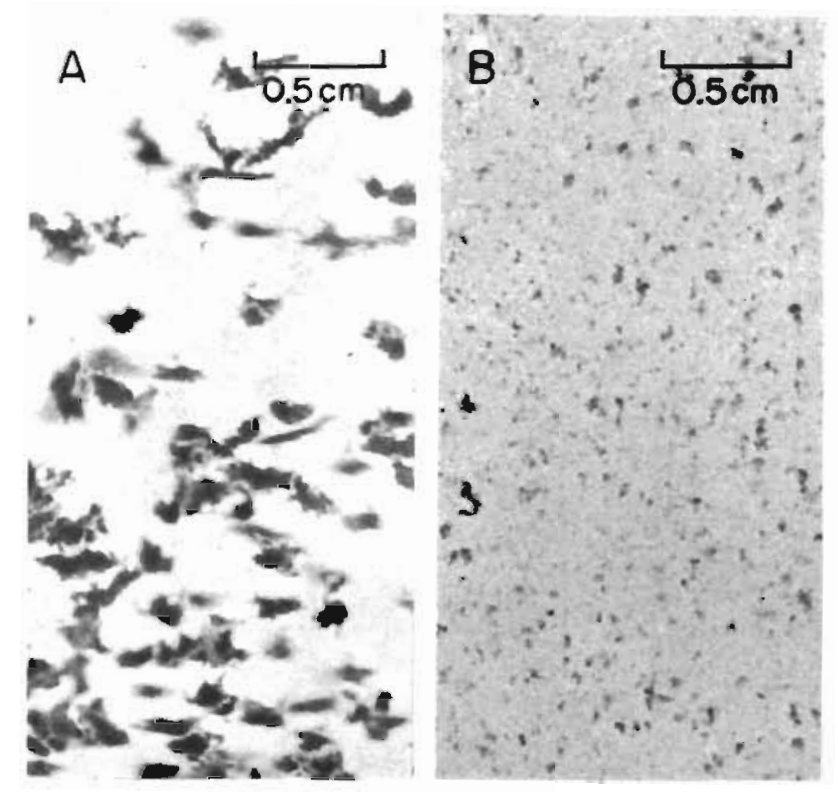

Fig. 2. (A) Macroflocs in suspension near boundary between clear suspension and particulate matter (Fig. 1 B). They are composed of $50 \%$ sediment and $50 \%$ organic matter produced from an initial concentration of $237 \mathrm{ppm}$ in a flow of $0.1 \mathrm{~cm} \mathrm{~s}^{-1}$. (B) Macroflocs in middle tube section formed near the start of experiment, using a $150 \mathrm{ppm}$ sediment suspension and a flow rate of $0.1 \mathrm{~cm} \mathrm{~s}^{-1}$
Table 1. Decrease of suspended-sediment concentration in upwelling tube employing three suspensions with different compositions and initial concentrations of $100-107 \mathrm{ppm}$

\begin{tabular}{|cccc|}
\hline $\begin{array}{c}\text { Hours } \\
\text { after start of } \\
\text { experiment }\end{array}$ & Sediment & $\begin{array}{c}\text { Concentration in ppm (particles } 1 \mu \mathrm{m}) \\
50 \% \text { Organic } \\
\text { matter }\end{array}$ \\
\hline $50 \%$ Sediment & $\begin{array}{c}\text { Organic } \\
\text { matter }\end{array}$ \\
\hline 24 & 56.23 & 18.84 & 36.10 \\
48 & 43.42 & 4.84 & 27.11 \\
96 & 36.90 & N.D. & 18.30 \\
192 & 23.20 & 0.7 & 1.87 \\
- Post glacial marine clay, Sillikers, N.B. \\
. 50\% fish and 50\% algae \\
\hline
\end{tabular}

ganic slurries also formed strings at low flow rates, but at high rates the flocs were usually irregular, with protrusions or star-like arms. When first formed the flocs appeared to be fluffy, irregular and diffuse, but by the time they reached the cone section they had consolidated into denser bodies of uniform shape and size. Typically, during the later stages of an experiment, the particulate matter had become concentrated in the cone, where it tumbled about as balls, star- or parachute-like bodies in the strong turbulence, while the rest of the suspension was clear (Fig. 1b, 2a). Some material also became stuck to the walls of the apparatus as large particles or as a thin coating, but the

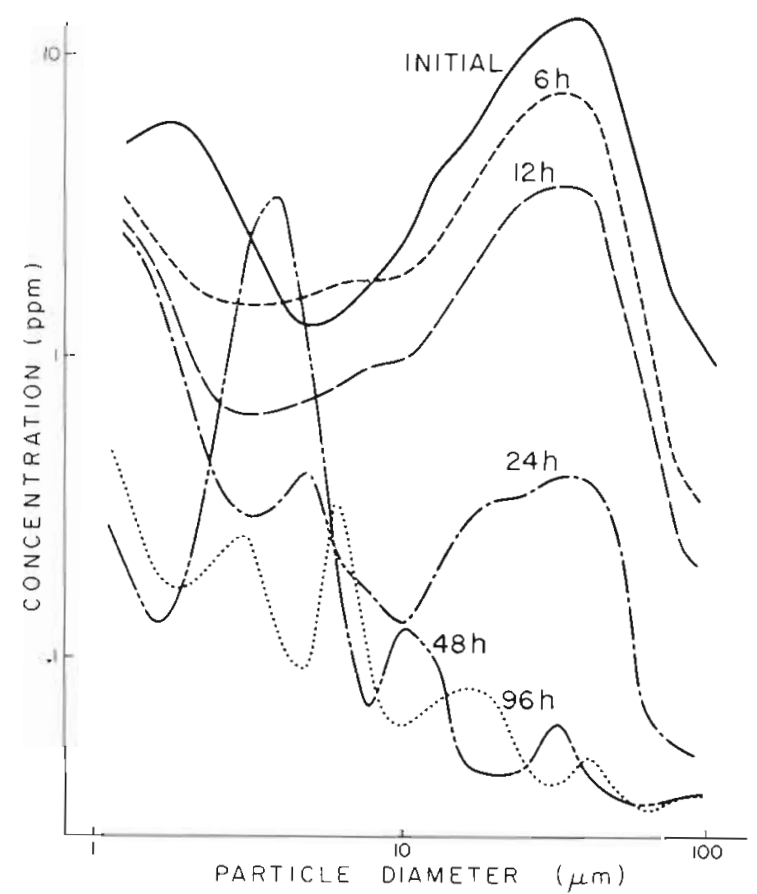

Fig. 3. Change in grain-size spectra of particulate organic matter sampled $15 \mathrm{~cm}$ below top of tube as measured by Coulter Counter. Flow rate in tube: $0.1 \mathrm{~cm} \mathrm{~s}^{-1}$; initial concentration: $125 \mathrm{ppm}$; concentration at $96 \mathrm{~h}: 2.5 \mathrm{ppm}$ 
amount lost in this way was usually not more than about $20 \%$ of the total. On one occasion circulation was continued for 2 months, at the end of which a solid plug had formed at the bottom of the cone. From its size and shape the volume was estimated. The plug disintegrated when extracted through the bottom spigot, but the material was recovered and weighed. This gave a density of 1.02 for this solid-looking sediment, which was formed from an initial slurry consisting of one half ground-up fish and algae and one half sediment by volume. In all experiments, the large flocs could not be extracted intact, but disintegrated on removal from the apparatus.

The rate of decrease in concentration of suspended matter in the tube was monitored during three experiments, using material of different composition (Table 1). Initial concentrations by volume and flow rates were the same in all 3 experiments. The rate of decrease varied considerably. The suspensions of organic matter settled (water cleared) much faster than the sediment suspension. The organic-inorganic mixture settled at the highest rate.

Changes in concentrations of different grain sizes followed a similar pattern in these experiments and in several others during which size distributions in the supernatant water were monitored. For example, Figure 3 shows the change in spectra with time in a suspension of ground-up plankton material (see above). These spectra represent a maximum stable grain-size distribution that survived sampling and counting. No particles larger than $200 \mu \mathrm{m}$ were measured, but abundant much larger flocs could be seen at the opening of the sampling tube, especially during the collection of the earliest samples, and must have been included in the withdrawal. Note that the spectra are shown as log-log plots to allow easy comparison between samples.

In the experiment illustrated (Fig. 3) the initial size distribution was binodal, with a $25 \mu \mathrm{m}$ mode composed of zooplankton fragments and detritus and a second mode about $2 \mu \mathrm{m}$ composed mainly of bacteria and detritus. During the first $12 \mathrm{~h}$ the absolute concentrations decreased progressively by over $80 \%$, but the relative concentrations of particle sizes remained about the same. From 12 to $24 \mathrm{~h}$, concentrations of the sizes making up the larger mode continued to decrease in the same proportional manner, but in the smallest size classes there was little or no decrease, apparently due to the growth of bacteria less than $2 \mu \mathrm{m}$ in size. After $48 \mathrm{~h}$ the bacteria were greatly reduced in number, but a flagellate bloom had formed a prominent peak at about $4 \mu \mathrm{m}$. This flagellate bloom was reduced in the 96-h sample and the concentration in the other sizes showed little change from previous samples. The experiment was not continued beyond
$96 \mathrm{~h}$. In experiments of longer duration, the concentration in any one size class was not reduced below $0.01 \mathrm{ppm}$, even after $96 \mathrm{~h}$, apparently because production of organic matter kept pace with the sinking rate.

\section{DISCUSSION}

The results show that fine-grained particulate matter suspended in sea water readily forms large, visible aggregates with high settling rates. Although our experimental conditions differed in many aspects from a natural environment, basic conditions were similar, and it is reasonable to suppose that the experiment simulates the formation of marine snow and allows for some discussion of the conditions necessary for its formation.

Aggregate formation fits the conditions for simple physio-chemical flocculation dependent on particle collision and adhesion. The organic material was prepared by grinding and used immediately, and the flocculation frequently started in the experimental tube within a few minutes from the time of injection. Turbulence causes particle collisions and Van der Vaals and electro chemical forces cause particle adhesion (Krone, 1978). In sea water even inorganic grains have a coating of organic matter which thus forms the reacting surface (Neihof and Loeb, 1974; Loeb and Neihof, 1977). Biological processes may play a role in strengthening the floc structure, but much longer reaction times would be expected if, for example, algal coatings or extracellular bacterial strands (Pfister et al., 1969; Dugan et al., 1971; Zabawa, 1978) were the primary aggregating agents.

The constancy of the relative grain-size distribution of the particles remaining in suspension during the early part of the experiments provides further evidence that the process of flocculation is mainly - if not wholly - physical, at least during the initial period. A similar pattern of change in total concentration without change in relative grain-size distribution was found during a study on settling of inorganic sediment suspended in electrolyte solution (Kranck, in press). It was concluded in that study that each floc contained all grain sizes present in the original suspension, and in the same proportion. Thus, as flocs settle out of suspension, the concentrations of all sizes decrease at the same relative rate, and the size spectra when plotted as log-log distributions preserve their shape (Fig. 3). Only when biological production, later in the experiment, adds living particles is there a change in the spectra. Some of the growth of small particles may be due to the transformation of 'dissolved organic matter' into particles larger than $1 \mu \mathrm{m}$ (minimum recorded by the Coul- 
ter Counter), due in part to the bubbling stone at the stop of the tube (Baylor and Sutcliffe, 1963).

It may be argued that in the experimental suspensions the concentrations were considerably higher than under open marine conditions, and that therefore interparticle collision is greatly enhanced. This is true, but in the sea the negative effect of interparticle distances is counterbalanced by longer residence times. No quantitative conclusions on flocculation rates applicable to nature are claimed here. The collection of flocs at the bottom of the cylinder also complicates attempts to model particle-interaction processes. Once the particles begin to concentrate in this region, they accelerate interparticle collision and act as a filter by capturing smaller grains flowing past.

Although absolute rates of settling in the tube are not significant because of the arbitrary conditions of the experiment, the relative rates of decrease of different materials are noteworthy (Table 1). The mixture of half inorganic and half organic matter settled faster than homogeneous suspensions of either organic material or sediment. Flocculation is promoted by particle collision. Differences in the settling rates of particles in a suspension increase the chances of collision as faster settling particles collide with slower settling ones. In a mixture of organic and inorganic matter settling rates will vary due to differences in densities as well as in size of the suspended grains. The combination of half sediment and half organic matter which resembles the suspended matter in many estuaries may be close to an optimum composition for flocculation. The organic particles may also act as binding agents, holding together the more inert inorganic particles.

Exact comparison between the turbulence in the tube and in the sea is difficult. The speed of $0.25 \mathrm{~cm} \mathrm{~s}^{-1}$ is close to the maximum found in areas of upwelling. Flocs formed and settled in water flow with speeds of one order of magnitude greater than that, and withstood disintegration in the cone, where shear forces were even higher. From this it can be concluded that flocs can form and settle under most naturally occurring turbulence levels.

The break-up of the flocs on sampling shows that they are unstable when subjected to stresses different from those under which they formed. The increase in natural suspended-matter concentrations at density interfaces and close to the bottom of the sea (Brewer et al., 1976; Derenbach et al., 1979) may at least partly result from the disintegration of settling flocs in these zones of changing shear forces.

Acknowledgements. We would like to thank Professor P. J. Wangersky and Dr. R. Pocklington for critically reviewing this manuscript.

\section{LITERATURE CITED}

Alldredge, A. L. (1976). Discarded appendicularian houses as source of food, surface habitats and particulate organic matter in planktonic environments. Limnol. Oceanogr. 21: $14-23$

Alldredge, A. L. (1979). The chemical composition of macroscopic aggregates in two neretic seas. Limnol. Oceanogr. 24: 855-866

Baylor, E. R., Sutcliffe, W. H., Jr. (1963). Dissolved organic matter in seawater as a source of particulate food. Limnol. Oceanogr. 4: 369-371

Bewers, J. M., Yeats, P. A. (1977). Oceanic residence times of trace metals. Nature, Lond. 268: 595-598

Bishop, J. K. B., Edmonds, J. M., Kellon, D. R., Bacon, M. P., Silker, W. B. (1977). The chemistry, biology, and vertical flux of particulate matter from the upper $400 \mathrm{~m}$ of the equatorial Atlantic Ocean. Deep Sea Res. 24: 511-548

Brewer, P. G., Spencer, D. W., Biscaye, P. E., Hanley, A., Sachs, P. L., Smith, C. L., Kadar, S., Fredericks, J. (1976). The distribution of particulate matter in the Atlantic Ocean. Earth Planet. Sci. Lett. 32: 393-402

Derenbach, J. B., Astheimer, H., Hansen, H. P., Leach, H. (1979). Vertical microscale distribution of phytoplankton in relation to the thermocline. Mar. Ecol. Prog. Ser. 1: 187-193

Drake, D. E. (1976). Suspended sediment transport and mud deposition on Continental Shelves. In: Stanley, D. J., Swift, D. J. F. (eds) Marine sediment transport and environmental management. John Wiley and Sons, New York, pp. 127-158

Dugan, P. R., Pfister, R. M., Frea, J. I. (1971). Implications of microbial polymer synthesis in waste treatment and lake eutrophication. In: Proceedings of the 5th International water pollution research conference, III-20/1-10. Pergamon Press Ltd., London

Edmond, J. M. (1974). On the dissolution of carbonate and silicate in the deep ocean. Deep Sea Res. 21:455-480

Gordon, D. C. (1970). A microscopic study of organic particles in the North Atlantic Ocean. Deep Sea Res. 17: 175-185

Hargrave, B. T., Taguchi, S. (1978). Origin of deposited material sedimented in a marine bay. J. Fish. Res. Bd Can. 35 : $1604-1613$

Honjo, S. (1977). Sedimentation of materials in the Sargasso Sea at a 5,367 m deep station. J. Mar. Res. 36: 474-475

Inoue, N., Nishizawa, S., Fukuda, M. (1955). The perfection of a turbidity meter and the photographic study of suspended matter and plankton in the sea using an undersea observation chamber. In: Proceeding UNESCO symposium on physical oceanography, Tokyo, pp. 53-58

Jannasch, H. W. (1973). Bacterial content of particulate matter in offshore surface waters. Limnol. Oceanogr. $18 ; 340-342$

Krisnaswami, S., Sarin, M. M. (1976). Atlantic surface particulates: composition, settling rate and dissolution in the deep sea. Earth Planet. Sci. Lett. 32: 430-440

Kranck, K. (1975). Sediment deposition from flocculated suspensions. Sedimentology 22: 111-123

Kranck, K. (1979). Dynamics and distribution of suspended particulate matter in the St. Lawrence Estuary. Naturaliste can. 106: 163-173

Kranck, K. (in press). Experiments on the significance of flocculation in the settling of fine grained sediment in still water. Can. J. Earth Sci.

Kranck, K., Milligan, T. (1979). The use of the Coulter Counter in studies of particle-size distributions in aquatic environments. Bedford Institute Report Series BI-R-79-7

Krone, R. B. (1972). A field study of flocculation as a factor in 
estuarial shoaling processes. Committee on Tidal Hydraulics, Corps, of Engineers, U.S. Army. Waterways Experimental Station, Vicksburg, Mississippi. Tech. Bull. 19

Krone, R. B. (1978). Aggregation of suspended particles in estuaries. In: Kerfve, B. (ed.) Estuarine transport processes. University of South Carolina Press, Columbia pp. $177-190$

Loeb, G. L., Neihof, R. A. (1977). Adsorption of an organic film at the platinum-seawater interface. J. mar. Res. 35: 283-291

Neihof, R., Loeb, G. (1974). Dissolved Organic matter in seawater and the electric charge of immersed surfaces. J. mar. Res. 32: 5-12

Nishizawa, S., Fukada, M., Inoue, N. (1954). Photographic study of suspended water and plankton in the sea. Bull. Fac. Fish. Hokkaido Univ. 5: 36-40

Pfister, R. M., Dugan, P. R., Frea, J. I. (1969). Microparticulates: Isolation from water and identification of associated chlorinated pesticides. Science, N. Y. 166: 878-879

Prahl, F. G., Carpenter, R. (1979). The role of zooplankton fecal pellets in the sedimentation of polycyclic aromatic hydrocarbons in Dabob Bay, Washington. Geochim Cosmochim. Acta 43: 1959-1972

Riley, G. A. (1963). Organic aggregates in seawater and the dynamics of their formation and utilization. Limnol. Oceanogr. 8: 372-381

Riley, G. A. (1970). Particulate organic matter in seawater. Adv. mar. Biol. 8: 1-118

Riley, G. A., Hement, D., Wangersky, P. J. (1963). Organic aggregates in surface and deep waters of the Sargasso Sea. Limnol. Oceanogr. 10: 354-363

Rowe, G. T., Gardner, W. D. (1979). Sedimentation rates in the slope water of the northwest Atlantic Ocean measured directly with sediment traps. J. mar. Res. 37: 581-600

Schubel, J. R. (1969). Size distribution of the suspended particles of the Chesapeake Bay turbidity maximum. Netherl. J. Sea Res. 4: 283-309

Shanks, A. L., Trent, J. D. (1979). Marine Snow: Microscale nutrient patches. Limnol. Oceanogr. 24: 850-854

Silver, M. W., Shanks, A. L., Trent, J. D. (1978). Marine Snow: Microplankton Habitat and source of small-scale patchiness in pelagic populations. Science, N. Y. 201: 371-373

Spencer, D. W., Brewer, P. G., Fleer, A., Honjo, S., Krishanaswami, S., Nozaki, Y. (1978). Chemical fluxes from a sediment trap experiment in the deep Sargasso Sea. J. Mar. Res. 36: 493-523

Suzuki, N., Kato, K. (1953). Studies on suspended materials marine snow in sea. Part I. Sources of marine snow. Hakkaido Univ. Fac. Fish. Bull. 4: 132-135

Trent, J. D., Shanks, A. L., Silver, M. W. (1978). In situ and laboratory measurements on macroscopic aggregates in Monterey Bay, California. Limnol. Oceanogr. 23: 626-635

Wiebe, P. H., Boyd, S. H., Winget, C. (1976). Particulate matter sinking to the deep-sea floor at $2000 \mathrm{~m}$ in the tongue of the ocean with a description of a new sedimentation trap. Mar. Res. 34: 341-355

Zabawa, C. F. (1978). Microstructure of agglomerated suspended sediments in Northern Chesapeake Bay Estuary. Science, N. Y. 20: 49-51

This paper was presented by Professor P. J. Wangersky; it was accepted for printing on April 9, 1980 